\title{
KESEPIAN DITINJAU DARI KUALITAS KOMUNIKASI PADA REMAJA DENGAN ORANGTUA TUNGGAL
}

\author{
Rizqa Ayu Savitri \\ Ratna Syifa'a Rahmahana \\ Fakultas Psikologi dan Ilmu Sosial Budaya Universitas Islam Indonesia
}

\begin{abstract}
The purpose of this research was to examine the relations between parent's communication quality and level of loneliness in their adolescence's children. The hypothesis was the higher the quality of parent's communication with their teen children, the less lonely they would be. The respondents were high School students with 14-20 years of age from single parents'family. Data collections were using Loneliness Scales (Weiss 1994; Mustikasari, 2002) and Communication Quality Scale (Laswell \& Laswell, 1987; Suwantoro, 1997). Data analyzes using statistical method with Product Moment Technique from Pearson. The parent's communication quality was found to be negatively correlated to teen's level of loneliness. The higher the quality of communication between parents with their teens children, the less lonely they would become $(r=-0,712 ; p=$ 0,000). The quality of communication itself contributed 50,7\% to the respondents' level of loneliness while 49,3\% of other factors still unidentified and need further investigation.
\end{abstract}

Keywords: quality of communication, loneliness, single parent.

Remaja adalah sosok yang diharapkan menjadi pengemban masa depan dan penerus cita-cita bangsa dan negara. Sebagai generasi penerus bangsa, diharapkan remaja mengoptimalkan potensi yang ada di dalam dirinya. Masa remaja adalah masa penuh dengan potensi yang perlu digali. Selain itu, pada masa ini remaja mengalami masa ketidakjelasan karena masa remaja merupakan masa transisi di mana individu mengalami perubahan baik fisik, psikis, maupun sosial yang tumbuh dari anak-anak menjadi dewasa.

Salah satu faktor utama yang mempengaruhi perkembangan sosial anak adalah faktor ketidakutuhan keluarga meliputi perceraian dan kematian salah satu orangtua. Beberapa penelitian menyebutkan bahwa remaja di bawah pengasuhan orangtua tunggal lebih banyak mempunyai masalah psikososial dibanding remaja dengan orangtua lengkap. Sebuah studi mengungkapkan bahwa remaja korban perceraian dan single parent lebih rentan untuk melakukan kekerasan, penyalahgunaan obat-obat terlarang, bunuh diri, drop-out dari sekolah, menjadi pengangguran, melakukan seks pranikah, dan mengalami perceraian di dalam kehidupan pernikahannya kelak (Khisbiyah, 1994). Mereka juga sering merasa tidak bahagia dan kesepian, mempunyai ketidakstabilan emosi (Khisbiyah, 1994).

Longfellow (Sears dkk, 1994) mulai berusaha memahami berbagai pengaruh perceraian terhadap anak. Salah satu kemungkinannya adalah bahwa anak akibat perceraian bisa menjadi lebih peka terhadap kesepian ketika mereka menginjak kedewasaan. Peplau dan Perlman (Byrne \& 
Baron, 2005) mendefinisikan kesepian sebagai suatu keinginan yang tidak terpenuhi untuk membangun hubungan interpersonal yang akrab. Menurut Sears dkk (1994), kesepian menunjuk pada kegelisahan subjektif yang dirasakan pada saat hubungan seseorang kehilangan ciri-ciri pentingnya. Hilangnya ciri-ciri tersebut bersifat kuantitatif, yaitu tidak mempunyai teman atau hanya mempunyai sedikit teman seperti yang diinginkan. Kekurangan itu dapat bersifat kualitatif, yaitu seseorang mungkin merasa bahwa hubungan sosialnya dangkal atau kurang memuaskan dibandingkan dengan apa yang diharapkan.

Kesepian yang terjadi pada remaja lebih disebabkan remaja tengah mengalami proses perkembangan yang kompleks. Perkembangan yang meningkatkan perasaan terisolasi, kebutuhan akan individu lain dan kecemasan terhadap masa depannya (Brennan dalam Adi, 2000). Akibat remaja kehilangan tempat berpegang untuk mencurahkan perasaannya. Mereka sering merasa tidak bahagia dan kesepian karena tidak adanya kepuasan dalam hal berkomunikasi dengan orang tuanya.

Hal yang diungkapkan di atas berkaitan dengan kualitas komunikasi pada remaja dengan orangtua tunggal, di mana remaja yang komunikasinya dengan orangtua tunggal rendah atau tidak berkualitas akan cenderung mengalami kesepian karena remaja menganggap bahwa dirinya tidak dimengerti dan dipahami oleh orang tuanya. Mereka merasa orang tua tidak menyayangi $\mathrm{m}$ e r e k a d a n c e $\mathrm{nd}$ e r u $\mathrm{n}$ mengkompensasikannya melalui tindakan yang agresif, frustrasi dan kesepian (Istyarini, 2001).

Purwanto (1988) mengemukakan bahwa kualitas komunikasi secara harfiah merupakan suatu derajat baik buruknya interaksi sosial, kontak sosial, kedua belah pihak, baik pihak pengirim maupun penerima. Kualitas yang baik dari komunikasi diartikan sebagai suatu keberhasilan dalam sebuah interaksi dan dinyatakan sebagai komunikasi yang efektif sedangkan kualitas yang buruk menandakan ketidakefektifan dari komunikasi.

Remaja yang komunikasi dengan orangtua tunggal lebih tinggi atau berkualitas akan cenderung untuk tidak merasa kesepian. Remaja yang mendapat bantuan untuk mengatasi masalah-masalah yang mereka hadapi dalam perubahan status keluarganya akan lebih merasa percaya diri dan mandiri sehingga menghindarkan diri mereka dari perasaan kesepian. Mereka mempercayai orangtua sebagai figur yang dapat memahami mereka dan dapat mencurahkan segala masalah yang mereka hadapi. Hal ini sesuai dengan pendapat Fuad (2005) yang mengatakan bahwa salah satu tugas orangtua adalah selalu berusaha mengerti perasaan remaja saat berkomunikasi dengan orangtua. Dengan perasaan positif dan terbuka, anak akan lebih mudah berkomunikasi sehingga tercipta komunikasi yang berkualitas.

Berdasarkan beberapa teori dan uraian yang telah dikemukakan di atas, maka hipotesis yang diajukan dalam penelitian ini adalah ada hubungan negatif antara kualitas komunikasi remaja-orangtua tunggal dan 
kesepian pada remaja. Semakin tinggi kualitas komunikasi, semakin rendah tingkat kesepian pada remaja. Semakin rendah kualitas komunikasi, semakin tinggi tingkat kesepian pada remaja.

\section{METODE PENELITIAN}

\section{Subjek Penelitian}

Subjek yang digunakan dalam penelitian ini adalah semua individu dengan karakteristik remaja perempuan dan lakilaki, berusia 14-20 tahun, dan memiliki orangtua yang bercerai atau meninggal salah satunya.

\section{Metode Pengumpulan Data}

Skala kesepian yang digunakan dalam penelitian ini adalah hasil modifikasi skala kesepian yang disusun oleh Mustikosari (2002) berdasar aspek-aspek kesepian. Skala kesepian terdiri dari 50 aitem meliputi 25 aitem pernyataan favourable dan 25 aitem pernyataan unfavourable. Semuanya mengukur emotional loneliness, social loneliness, dan situstional loneliness mengenai kepuasan dan ketidakpuasan dalam hubungan sosial.

Skala kualitas komunikasi yang digunakan dalam penelitian ini adalah hasil modifikasi dari skala kualitas komunikasi yang disusun oleh Suwantoro (1997). Skala ini terdiri dari 50 pernyataan yang mengukur aspek-aspek kualitas komunikasi, yaitu keterbukaan, kejujuran, kepercayaan, empati dan mendengarkan.

\section{Teknik Analisis Data}

Analisis data dalam penelitian adalah analisis statistik yang digunakan secara kuantitatif. Pengujian hipotesis pada penelitian ini menggunakan uji bivariate corellation dengan teknik korelasi product moment dari Pearson yang terdapat pada program statistik SPSS 12 for window XP.

\section{HASIL PENELITIAN}

\section{Deskripsi Data}

Tabel 1. Deskripsi Data Penelitian Secara Keseluruhan

\begin{tabular}{|c|c|c|c|c|c|c|}
\hline \multirow[b]{2}{*}{ Variabel } & \multicolumn{3}{|c|}{ Empirik } & \multicolumn{3}{|c|}{ Hipotetik } \\
\hline & $\mathrm{X} \max$ & $\mathrm{X} \min$ & Mean SD & $\mathrm{X} \max$ & & Mean SD \\
\hline Kesepian & 98 & 38 & $64,95 \quad 13,34$ & 124 & 31 & $77,5 \quad 15,5$ \\
\hline $\begin{array}{l}\text { Kualitas } \\
\text { Komunikasi } \\
\end{array}$ & 112 & 42 & $82,25 \quad 13,95$ & 116 & 29 & $72,5 \quad 14,5$ \\
\hline \multicolumn{7}{|c|}{ Tabel 2. Deskripsi Kategorisasi Kesepian } \\
\hline Variabel & Katego & & \multirow{2}{*}{$\begin{array}{l}\text { Skor } \\
X=49,6\end{array}$} & Frekwer & & Prosentase \\
\hline \multirow[t]{5}{*}{ Kesepian } & \multicolumn{2}{|c|}{ Sangat Rendah } & & 6 & & \multirow{2}{*}{$\begin{array}{c}10,72 \% \\
50 \%\end{array}$} \\
\hline & \multirow{2}{*}{\multicolumn{2}{|c|}{ Rendah }} & $49,6<X=68,2$ & \multicolumn{2}{|l|}{28} & \\
\hline & \multirow{2}{*}{\multicolumn{2}{|c|}{$\begin{array}{l}\text { Sedang } \\
\text { Tinggi }\end{array}$}} & $68,2<X=86,8$ & \multicolumn{2}{|c|}{18} & $32,14 \%$ \\
\hline & & & $86,8<X=105,4$ & 4 & & $7,14 \%$ \\
\hline & \multicolumn{2}{|c|}{ Sangat Tinggi } & $X>105,4$ & \multicolumn{2}{|l|}{0} & $0 \%$ \\
\hline
\end{tabular}

Tabel 3.Deskripsi Kategorisasi Kualitas Komunikasi

\begin{tabular}{lcccc}
\hline Variabel & Kategori & Skor & Frekwensi & Prosentase \\
\hline Kualitas & Sangat Rendah & $\mathrm{X}=46,4$ & 1 & $1,79 \%$ \\
Komunikasi & Rendah & $46,4<\mathrm{X}=63,8$ & 4 & $5,35 \%$ \\
& Sedang & $63,8<\mathrm{X}=81,2$ & 20 & $37,5 \%$ \\
& Tinggi & $81,2<\mathrm{X}=98,6$ & 26 & $46,43 \%$ \\
& Sangat Tinggi & $\mathrm{X}>98,6$ & 5 & $8,93 \%$ \\
\hline
\end{tabular}

\section{Hasil Uji Asumsi}

Uji normalitas menggunakan teknik one-sample Kolmogorof-Smirnov Test dari program SPSS 12.00 for windows untuk skala kesepian adalah Normal $(\mathrm{K}-\mathrm{SZ}=$ 0,603; $\mathrm{p}>0.05$ dengan nilai $\mathrm{p}=0,860$ ). Sementara itu skala kualitas komunikasi juga Normal $(\mathrm{K}-\mathrm{SZ}=0,506 ; \mathrm{p}>0.05$ dengan nilai $\mathrm{p}=0,960)$.

Uji linieritas skala kesepian terhadap skala kualitas komunikasi Linear menunjukkan $(\mathrm{F}=68,537 ; \mathrm{p}<0,00$ dengan $\mathrm{n}$ i 1 a i $\mathrm{p}=0,00 \quad$ ). 


\section{Hasil Uji Korelasi}

Uji korelasi dari Pearson dengan menggunakan teknik bivariate correlation diperoleh hasil bahwa besarnya koefisien korelasi sebesar $\mathrm{r}=-0,712 ; \mathrm{p}=0,000$. Karena $\mathrm{p}<0,01$, maka hipotesis penelitian yang mengatakan ada hubungan negatif antara kualitas komunikasi remaja-orangtua tunggal dengan kesepian pada remaja diterima. Koefisien determinasi (R squared) variabel kualitas komunikasi terhadap variabel kesepian sebesar 0,507 sehingga sumbangan efektif yang dapat diberikan variabel kualitas komunikasi terhadap variabel kesepian adalah 50,7\%.

\section{PEMBAHASAN}

Berdasarkan hasil uji hipotesis yang telah dilakukan, didapatkan hasil penelitian bahwa terdapat hubungan negatif yang signifikan antara kualitas komunikasi remaja-orangtua tunggal dan kesepian pada remaja. Hal ini berarti bahwa hipotesis yang diajukan dalam penelitian ini diterima. Artinya bahwa bila kualitas komunikasi remaja-orangtua tunggal tinggi, maka tingkat kesepian pada remaja rendah. Begitu juga sebaliknya, jika kualitas komunikasi remaja-orangtua tunggal rendah maka tingkat kesepian pada remaja menjadi tinggi.

Hal tersebut $\mathrm{d}$ atas juga didukung oleh hasil kategorisasi yang dihasilkan oleh responden dalam penelitian ini. Hasil pengkategorisasian dengan membandingkan mean hipotetik dan mean empirik pada skala tingkat kesepian berada dalam kategori rendah, yaitu sebesar $50 \%$, sementara itu hasil kategorisasi dengan membandingkan mean hipotetik dan mean empirik pada skala kualitas komunikasi berada pada tingkat tinggi, yaitu sebesar 46,43\% menunjukkan bahwa sebagian Subjek tidak mengalami kesepian.

Sumbangan efektif yang bisa diberikan variabel kualitas komunikasi terhadap variabel kesepian adalah 50,7 \% sedangkan sumbangan lain tersisa 49,3\% merupakan sumbangan faktor lain yang dapat menjadi pemicu munculnya kesepian pada remaja yaitu proses perkembangan, struktur sosial dan proses kultural, serta karakteristik pribadi.

Hasil penelitian menunjukkan bahwa adanya hubungan negatif antara kualitas komunikasi remaja-orangtua tunggal dengan kesepian pada remaja. Semakin tinggi kualitas komunikasi remaja-orangtua tunggal maka semakin rendah kesepian yang dialami oleh remaja, sedangkan semakin rendah kualitas komunikasi remaja-orangtua tunggal, maka semakin tinggi kesepian yang dialami oleh remaja. Maksudnya adalah komunikasi yang baik dalam keluarga akan mendukung kelancaran proses perkembangan remaja dalam rangka membentuk kepribadian. Jika orangtua yang menyandang status orangtua tunggal membiasakan diri meluangkan waktu bersama, maka akan tercipta komunikasi antara remaja dan orangtua tunggal, sehingga remaja merasa tidak kesepian.

Sesuai dengan yang dikemukakan oleh De Vito (1995) bahwa salah satu peranan komunikasi adalah untuk mengurangi rasa kesepian. Sebagaimana kita ketahui bahwa remaja dengan orangtua 
tunggal dapat menjadi lebih peka terhadap kesepian (Longefellow dalam Sears, 1994). Kesepian pada remaja tersebut timbul karena remaja kehilangan tempat mengadukan perasaannya seperti rasa kecewa, konflik, dan stress akibat perubahan status keluarganya. Kurangnya perhatian orangtua (tunggal) tentu akan mempengaruhi perkembangan jiwa anak. Merasa kasih sayang orangtua yang didapatkan tidak utuh, anak akan mencari perhatian dari oranglain atau bahkan ada yang merasa malu, minder dan tertekan.

Lake (1986) mengungkapkan bahwa individu yang mengalami kesepian pada umumnya membutuhkan individu lain untuk diajak berkomunikasi dan membina suatu hubungan yang akrab. Dalam hal ini keterlibatan orangtua tunggal untuk menjauhkan remaja dari kesepian sangat diperlukan, salah satunya adalah dengan meningkatkan kualitas komunikasi. Komunikasi yang berhasil bukan hanya sekedar kepandaian berbicara, melainkan komunikasi itu sendiri bersifat efektif atau berkualitas. Yang menjadi soal bukanlah berapa kali komunikasi dilakukan, tetapi bagaimana komunikasi itu dilakukan (Rakhmat, 2005).

Komunikasi merupakan faktor dominan penentu keberhasilan suatu keluarga bahagia. Menurut Mönks dkk (1999), komunikasi mutlak diperlukan dalam keluarga karena berfungsi bagi pembentukan pribadi anggotanya. Terlebih remaja yang masih berada dalam masa transisi dan sering mengalami dilema, merupakan anggota keluarga yang paling membutuhkan adanya komunikasi. Komunikasi merupakan komponen penting bagi perkembangan anak karena komunikasi berfungsi untuk memperbaiki hubungan anak dengan orangtua, sehingga mempermudah internalisasi nilai-nilai orangtua pada anak.

Wesserman dan Darwis (Rakhmat, 2005) mengemukakan bahwa kurangnya komunikasi akan menghambat perkembangan kepribadian (personal patology). Di samping itu komunikasi berkaitan erat dengan perilaku dan pengalaman kesadaran manusia yaitu sesuatu yang berpengaruh pula terhadap perkembangan kepribadian individu karena pola-pola interaksi maupun proses pertumbuhan dan perkembangan individu terbentuk didalam dirinya.

Orangtua yang bercerai atau kehilangan pasangan hidupnya cenderung tidak dapat menciptakan suasana yang sehat bagi anaknya. Orangtua terlalu sibuk dan terfokus dengan peristiwa tersebut sehingga mengabaikan remaja yang pada saat itu juga harus melakukan adaptasi dengan situasi keluarga yang berubah, sehingga terjadilah mis-communication yang biasanya ditandai dengan sulitnya orangtua membuat remaja paham dan mengerti tentang maksud yang diinginkan, dan remaja sendiri sulit memahami apa maksud orangtua terhadap dirinya. Remaja yang diasuh oleh orangtua tunggal memiliki cenderung memiliki hubungan komunikasi yang kurang baik dengan orangtuanya.

Komunikasi yang baik dan berkualitas dalam keluarga dengan orangtua 
tunggal sangat diperlukan untuk mendukung kelancaran proses perkembangan anak. Jika orangtua tunggal mampu menerapkan komunikasi secara terbuka, dan orangtua mau menjadi tempat mencurahkan perasaan anaknya sehingga dapat menghindarkan remaja dari perasaan kecewa dan kesepian saat menghadapi perubahan situasi keluarganya. Bila komunikasi antara orangtua dan remaja bersifat terbuka, maksud dan tujuan yang ingin disampaikan sudah jelas serta ekspektasi kedua belah pihak sudah dinyatakan maka akan tumbuh sikap percaya remaja terhadap orangtua.

Hopson (Amrillah, 2006) mengatakan bahwa komunikasi antara orangtua dan remaja dikatakan berkualitas apabila kedua belah pihak memiliki hubungan yang baik dalam arti bisa saling memahami, saling mengerti, saling mempercayai dan menyayangi satu sama lain, sedangkan komunikasi yang kurang berkualitas mengindikasikan kuarngnya perhatian, pengertian, kepercayaan dan kasih sayang diantara keduanya.

Weiss (Stevenson \& Black, 1995) mengamati bahwa anak-anak yang hidup dalam keluarga dengan orangtua tunggal lebih diposisikan sebagai rekan bagi orangtua mereka. Maksudnya kedudukan anak tersebut dijadikan sebagai teman dan pengganti dari salah satu orangtua mereka termasuk dalam pengambilan keputusan didalam keluarga dan juga menyelesaikan permasalahan yang ada didalam keluarganya.

Jika dilihat dari lima aspek yang terdapat pada alat ukur kualitas komunikasi, yaitu keterbukaan, kejujuran, empati, mendengarkan, dan kepercayaan sesuai data yang telah diperoleh dan sudah dianalisis. Hal ini bisa dilihat dari nilai $\mathrm{F}$ hitung $=2,556$ dan $\mathrm{p}=0,065(\mathrm{p}<0,05)$ dengan maka tidak ada perbedaan yang signifikan terhadap kelima aspek yang telah diberikan di SMUAl Irsyad Al Islamiyyah dan SMU Muhammadiyah 5. Menghadapi remaja memang bukan pekerjaan mudah. Menurut Adams dan Gullota (Sarwono, 2006), ada lima aturan untuk membantu remaja dalam menghadapi masalah mereka. Yang pertama adalah trustworthiness (kepercayaan), yaitu kita harus saling percaya dengan para remaja yang kita hadapi. Tanpa itu jangan diharap ada komunikasi dengan mereka. Yang kedua adalah genuineness, yaitu maksud yang murni, tidak pura-pura. Ketiga adalah empathi, yaitu kemampuan untuk ikut merasakan perasaan-perasaan remaja. Keempat adalah honesty, kejujuran. Selanjutnya, yang terakhir tetapi terpenting adalah adanya pandangan dari pihak remaja bahwa orangtua memang memenuhi keempat aturan tersebut.

Dari hasil analisis tambahan didapatkan kesimpulan bahwa tidak ada perbedaan tingkat kesepian antara remaja laki-laki dan remaja perempuan. Hal ini sesuai dengan hasil penelitian yang dilakukan oleh beberapa peneliti. Di antaranya adalah penelitian yang dilakukan oleh Margalit (Yu, Zan \& Yan, 2005) menyatakan bahwa tidak adanya perbedaan tingkat kesepian yang signifikan antara lakilaki dan perempuan. Theeke (2007) menyatakan hal yang sama yaitu bahwa 
perbedaan jenis kelamin bukan penyebab seseorang mengalami kesepian. Studi yang dilakukan oleh Burns (1988) menyatakan bahwa kesepian mempengaruhi baik pria maupun wanita dari segala umur.

Menurut Hall (Sarwono, 2006) remaja mempunyai rentangan umur dari 1225 tahun. Masa ini adalah masa yang paling rentan terhadap kesepian (Brennan dalam Baron \& Byrne, 2005; Brigham, 1991). Kesepian yang terjadi pada remaja baik lakilaki dan perempuan lebih disebabkan karena tengah mengalami proses perkembangan yang meningkatkan perasaan terisolasi, kebutuhan akan individu lain. Dari segi positifnya, remaja dapat menyerap informasi dari dunia orang dewasa secara kreatif dan menciptakan perkembangan hubungan pertemanan dengan sebaya yang unik (Corsaro \& Eder dalam Minzi, 2004). Interaksi remaja dengan teman sebaya sangat berperan dalam mendukung proses sosialisasi terhadap lingkungan.

Mengingat remaja masih berada pada tahap perkembangan fisik, emosional, intelektual, maupun spiritual, di mana pada masa-masa itu terjadi perubahan-perubahan yang cukup berpengaruh terhadap perkembangan sosial remaja khususnya terhadap hubungannya dengan orangtua tunggal. Hubungan komunikasi yang baik dan berkualitas antara remaja dengan orangtua tunggal akan membantu meningkatkan hubungan serta membantu remaja untuk terhindar dari perasaan kesepian, sedangkan komunikasi yang buruk antara remaja dengan orangtua tunggal akan mengganggu hubungan tersebut dan cenderung mengarah pada konflik dan kesepian pada remaja.

Kelemahan dari penelitian ini adalah tidak adanya pembedaan diantara Subjek dengan orangtua yang bercerai dan orangtua yang meninggal. Subjek dengan orangtua bercerai mempunyai konflik yang berbeda dengan Subjek yang orangtuanya meninggal. Sehingga Subjek yang digunakan tidak ada pengkategorian secara khusus baik dari status perpisahan orangtua maupun status Subjek tinggal bersama ayah atau ibu tunggal yang mempunyai konflik tersendiri.

\section{SIMPULAN DAN SARAN}

\section{Simpulan}

Hasil penelitian menunjukkan, bahwa ada hubungan negatif yang signifikan antara kualitas komunikasi remaja-orangtua tunggal dengan kesepian pada remaja. Bila kualitas komunikasi remaja-orangtua tunggal tinggi maka kesepian pada remaja rendah, dan sebaliknya jika kualitas komunikasi remaja-orangtua tunggal rendah maka kesepian pada remaja tinggi.

\section{Saran}

Proses dan hasil penelitian yang ditemukan ada beberapa hal yang dapat disarankan, saran tersebut antara lain sebagai berikut:

1. Bagi Subjek penelitian.

Dengan adanya penelitian ini diharapkan dapat membantu remaja yang mempunyai orangtua tunggal menyadari bahwa komunikasi sangat diperlukan dalam keharmonisan keluarga. Komunikasi yang dilandasi dengan keterbukaan, 
kepercayaan, empati, kejujuran dan mendengarkan dengan seksama dapat menghindarkan remaja dari kesepian yang dapat menimbulkan hal-hal negatif yang dapat merugikan diri remaja itu sendiri.

2. Bagi orangtua.

Dari hasil penelitian ini juga dapat membantu orangtua agar menciptakan suasana kehidupan rumah tangga yang normal walaupun dengan statusnya sebagai orangtua tunggal. Dengan komunikasi yang baik, terbuka dan saling memahami dapat membuat komunikasi yang seimbang antara orangtua tunggal dan remaja, yang menimbulkan hubungan yang harmonis antara keduanya dan dapat membangun suasana keterbukaan dan kesediaan saling mendengarkan satu sama lain. Dengan sifat komunikasi seperti itu, sangat diharapkan remaja mau berbicara secara terbuka kepada orangtua tunggal setiap kali remaja menghadapi permasalahan, menghargai apa pun yang disampaikan ketika orangtua tunggal berbicara, dan bersedia menyelesaikan masalah sendiri dengan bimbingan orangtua tunggal tanpa ada ketergantungan berlebihan.

3. Bagi peneliti selanjutnya.

Saran bagi peneliti selanjutnya yaitu pertama, bagi peneliti yang tertarik dengan tema yang sama diharapkan menggunakan metode penelitian kualitatif. Ini dikarenakan metode kualitataif dirasa sebagai metode yang tepat untuk menggali segala informasi dari Subjek mengenai komunikasi dengan orangtua tunggal. Selain wawancara mendalam, diperlukan juga observasi dan wawancara langsung dengan orangtua sehingga mendukung data yang diambil. Yang kedua, peneliti sebaiknya lebih cermat dalam memilih aitem-aitem yang lebih sesuai dengan keadaan remaja sehingga aitem dari kedua variabel tidak banyak yang gugur. Yang ketiga, sebaiknya peneliti lebih mengkhususkan perbedaan Subjek penelitian. Perlu diingat bahwa peristiwa perceraian dan kematian orangtua memiliki konflik yang berbeda. Sehingga diperlukan pembedaan Subjek remaja dengan orangtua yang bercerai dengan remaja yang orangtuanya meninggal dunia.

\section{DAFTAR PUSTAKA}

Anonim. (2005). Profil SMU "Plus" Al Irsyad Al Islamiyyah Cilacap. h t t $p: / / w w w$. al - irs y ad clp.sch.id.26/9/07

Adi, R. MC. (2000). Perbedaan Tingkat Kesepian pada Remaja di tinjau dari Status Pacaran. Skripsi (tidak diterbitkan). Fakultas Psikologi Universitas Gajah Mada.

Baron, R.A. \& Byrne, D. (2005). Psikologi Sosial. Jakarta: Erlangga (Alih Bahasa: Ratna Djuwita).

Brigham, J.C. (1991). Social Psycholgy $2^{n d}$ Edition. New York: HarperCollins Publishers Inc.

Burns, D., (1988). Mengapa Kesepian. Jakarta: Penerbit Erlangga. 
De Vito, J. (1995). The Interpersonal Communication $7^{\text {th }}$ edition. New York: HarperCollin College Publishers.

Fuad, F. (2005). Menjadi Orang Tua Bijaksana.. Yogyakarta : Tugu Publishers.

Galvin, K. \& Brommel, B. (1991). Family Communication, Cohesion and Change. New York: Harper Collins Publishers.

Istyarini, D. (2001). Menjadi Orangtua $\begin{array}{lllllll}\mathrm{T} & \mathrm{u} & \mathrm{n} & \mathrm{g} & \mathrm{g} & \mathrm{a} & 1\end{array}$ http://www.indomedia.com/intsari.1 6/10/07

Khisbiyah, Y. (1994). Family Dynamics, Family Breakups and Their Impacts on Children. Buletin Psikologi, Tahun II, Nomor 2, Desember.

Lake, T. Kesepian. (1986). Jakarta: Penerbit Arcan.

Minzi, M,. (2004). Development of Coping Resources in Childhood and Adolescence. Interdisciplinaria, Numero Especial.

Mustikosari, G. (2002). Hubungan Religiusitas dan Kesepian pada Remaja. Skripsi (tidak diterbitkan). Fakultas Psikologi Universitas Gajah Mada.

Myers, D. (1990). Social Psychology $3^{\text {rd }}$ edition. US America: McGraw-Hill Publishing Company.

Purwanto. (1988). Komunikasi Interpersonal Dalam Keluarga. Laporan Penelitian (tidak diterbitkan). Yogyakarta: Gadjah Mada University Press.

Rakhmat, J. (2005). Psikologi Komunikasi. Bandung: Remaja Rosdakarya.

Rohmah, F. (2004). Pengaruh Pelatihan Harga Diri terhadap Penyesuaian Diri Pada Remaja. Humanitas; Indonesian Psychology Journal Vol.
1 No. 1 Januari 2004. Yogyakarta: Fakultas Psikologi Universitas Ahmad Dahlan.

Sarwono, S.W. (2006). Psikologi Remaja. Jakarta : PT. Raja Grafindo Perkasa.

Sears, D.O., Taylor, S. \& Peplau, L.A. (1994). Social Psychology. New Jersey: Prentice Hall, Inc.

Stevenson, M.R., \& Black, K.N. (1995). How Divorce Affect Offspring: A Research Approach. USA: Brown \& Benchmark Inc

Steinberg. (2002). Adolescence $6^{\text {th }}$ Edition. Boston: McGraw Hill.

Suwantoro, A.A. (1997) Kepuasan Perkawinan ditinjau Dari Kualitas Komunikasi pada Pasangan Suami Istri. Skripsi (tidak diterbitkan) Fakultas Psikologi Universitas Gadjah Mada.

Theeke, L., (2007). Sociodemographic and Health-Related Risk for Loneliness and Outcome Differences by Loneliness Status in a Sample of Older U.S Adults. Disertasi. School of Nursing in West Virginia University. Morgantown.

Tim Penyusun. (2005). Kamus Besar Bahasa Indonesia Edisi Ketiga. Pusat Bahasa Departemen Pendidikan Nasional. Jakarta: Bakti Pustaka.

Yu, Guoliang., Zhang, Y., \& Yan, R. (2005). Loneliness, Peer Acceptance, and Family Functioning of Chinese Children With Learning Disabilities: Characteristic and Relationships. Psychology in the School, Vol. 42 ( 3 ). Published Online in Wiley

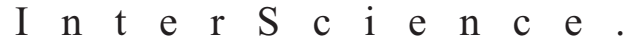
www.intersience.wiley.com.24/11/07

Yulianti, J.(2003). Mengapa Anda $\mathrm{M}$ e n g a $1 \mathrm{am}$ i K e s e p i a n. http://www.platon.co.id.27/12/07 